\title{
Reversal of Gender Roles in Twin Peaks and Fire Walk with Me
}

\author{
By Antonio Sanna \\ Spring 2012 Issue of KINEMA
}

\section{LAURA PALMER WAS BOB'S MASCULINE DAUGTER: REVERSAL OF GENDER ROLES IN TWIN PEAKS AND FIRE WALK WITH ME}

\begin{abstract}
In my paper I shall analyse the cult TV series Twin Peaks through a gender perspective. I shall argue that Laura Palmer could actually be seen as BOB's daughter because she impersonates male predatory sexuality and attitudes. I shall also argue that the behaviour of BOB could be seen as very similar to that of all of his victims through the same masculine attitudes they exhibit. In my reading, the series and the film will be considered as an unfolding narrative resulting from the comprehensive work of both its creators David Lynch and Mark Frost and the team of its writers and directors.

THE CONTROVERSIAL and much-debated TV series Twin Peaks by David Lynch and Mark Frost was divided in two seasons which were aired between 1990 and 1991; it was the most video-taped program on network television during the time of its airing, with over 830,000 persons recording it each week (Jenkins 67). It received initially an enthusiastic critical reaction and achieved a massive popularity, which still lasts after twenty years of its original airing. Indeed, the DVD collections of its two series as well as its soundtrack have been recently re-issued on the market (the "Gold Box Edition" was issued in 2007) and critical readings of its narrative are still being published, especially in volumes which analyse David Lynch's entire oeuvre. The story narrates of FBI special agent Cooper (Kyle MacLachlan) who is sent to the remote provincial town of Twin Peaks in North America, where the seventeen-year-old Laura Palmer (Sheryl Lee) has been brutally murdered. Cooper manages to identify the killer as Laura's father Leland (Ray Wise), who is revealed to be under the diabolic possession of a malevolent spirit called BOB (Frank Silva). Leland was forced by BOB to rape his own daughter since she was twelve and to kill her identical cousin Maddy Ferguson (Sheryl Lee) as well as Laura's friend and accomplice in prostitution Teresa Banks (Pamela Gidley). After Leland's capture and suicide, Cooper discovers that the spirit BOB comes from a place called the Black Lodge, a sort of afterlife in which the souls of the living linger after bodily death. The second and final season of the series terminates with agent Cooper's visit to the Black Lodge and his subsequent death because of the influence and possession by BOB.
\end{abstract}

During the past twenty years, many critics have attempted to explain the various representations and images present in the series without however establishing a unifying or single perspective capable of explaining the ideologies and meaning(s) of it. This is partly due to the fact that the series does not present a finished narrative: it was indeed cancelled by the ABC Network because of the huge drop in ratings after the revelation of the identity of Laura's killer in the middle of the second season. ${ }^{(1)}$ This decision thus forced the producers to abruptly terminate many of the narrative lines of the story in its "inconclusive" (Stewart 48) ending. The prequel film Fire Walk with Me by David Lynch (released one year after the cancellation of the series) is focused on the last seven days of Laura and her uncovering the truth (that the audience already knows) about the identity of her rapist and killer.

The film, however, does not actually clarify many hints and details of the series' narrative and even further contributes to the complexity of its meaning. Gender readings constitute a consistent part of the critical material on Twin Peaks: critics such as Lori Phelps (4), John Richardson (81), Diane Stevenson (74) and Diana Hume George (117) have particularly focused on the series' depiction of the relationship between patriarchy and women as well as on the dualities on which the representation of bourgeois society is based. My argument shall add another perspective to the debate hitherto made by means of the suggestion that the behaviour of BOB is coincident with that of all of his victims (in particular, Teresa Banks, Laura and Maddy Ferguson) because of the same masculine attitudes such victims exhibit. In my argument, BOB shall be interpreted as a representative of the patriarchal order, who murders the characters who do not respect the proper behaviour attributed to the respective sexes by such an order and who enact, instead, a reversal of gender roles on a public and visible level. I shall specifically argue that, since Leland Palmer has been 
possessed by the spirit of BOB from a young age, Laura could actually be seen as BOB's daughter. Laura impersonates male predatory sexuality and attitudes and is killed by her father for this very reason.

Reversal of gender roles is characteristic of the whole series. As Christy Desmet has noted, women such as Catherine Martell (Piper Laurie), Josie Packard (Joan Chen) and Norma's mother (Jane Greer) are depicted as strong and resolute, but they are granted power over other individuals only when they "are androgynous or masquer ad[ing] as men" (103). The female characters of the series have therefore power over the male characters only when behaving themselves like males. The most powerful woman represented in Twin Peaks is Catherine Martell, the virago who runs the local sawmill and possesses a conspicuous financial empire.

In "Episode 7" (the final episode of the first season, directed by Mark Frost), Catherine is betrayed by her accomplice and lover Benjamin Horne (Richard Beymer) and lured to the sawmill precisely when a bomb explodes setting the building on fire. After a few episodes in which the other characters of the series as well as the viewer expect her to be dead, Catherine reappears as cross-dressed, pretending to be a Japanese businessman. As we can see in "Episode 14" (directed by David Lynch), she modifies her voice and strictly talks only about business concerns and money, with no consideration for the problems caused on the local community by the fire which allegedly killed her. Catherine is cold, determinate in her actions and has a commanding disposition. Nevertheless, it is only by acting like a man as well as by means of her crossdressing disguise that she is able to gain total control of the town's most important financial affairs and to rebuild her own economic fortune. It is by posing like a man, by using a male tone of voice and speaking a male language of affairs and business that she manages to destroy her rival Benjamin Horne's decennial empire and to cause his psychological breakdown.

It is important to note, however, that Catherine Martell's masculine behaviour is not publicly condemned or punished because she acts secretly, actually behaving according to bourgeois rules. These rules, as Tom O'Connor has suggested, force the "majority of the characters in Twin Peaks [to] lead double, secret lives, in order to seek the fulfilment of their desires in a realm that does not openly challenge bourgeois myth" (319). Such a realm is represented by the authors and directors of the series as the bourgeois home. The "normal" appearance which must be displayed on a public level can be challenged only in the private environment of the house (O'Connor 317). In this respect, all of Catherine Martell's masculine actions (hence, transgressive to her sex) are shown as conducted in the dark and in the most secretive way, far from the eyes of the surrounding community. Indeed, it is inside her home that she spies on her rivals' conversations, she plots the down-fall of her enemies with cold detachment, and she even hides her own elder brother Andrew (Dan O'Herlihy) while arranging the revenge for the attempt on his life. Catherine is also the only woman of the series who is shown as confident when handling a gun.

Contrary to Shelley Johnson (Mädchen Amick) or Josie Packard (who both tremble when handling a weapon), Catherine is not scared at all when pointing a gun at Thomas Heckart's personal assistant Miss Jones (Brenda Strong) in "Episode 24" (directed by James Foley). However, she acts in such a cold and masculine manner only when far from the glances of the rest of society. This secrecy is epitomized by the very fact that she repeatedly hides valuable and important objects such as her gun and the sawmill's account books in different locations of her house. The masculine behaviour she enacts is therefore confined to the secrecy of the domestic walls. It is for this reason, we could suggest, that she is one of the few characters who survives at the end of the second series, though being engaged in illegal practices and exhibiting a male attitude contrary to her gender. The viewer would have easily expected Catherine to be killed in the bomb explosion at the bank which exterminates the rest of her family in "Episode 29" (directed by David Lynch). She is, however, shown as strong and intelligent enough not be caught in her rival Thomas Heckardt's (David Warner) mortal trap. In spite of the curiosity and suspense provoked in her whole family (as much as in the viewer of the series) by the enigmatic set of Chinese boxes given to her by Heckart's assistant, she avoids the final involvement in the deadly trap they conceal. She even appears to willingly let her brother Andrew steal the key of the safe-deposit box which contains the bomb in order not to risk any dangers herself.

Nevertheless, the reversal of gender roles is fully actuated through the representation of Leland and Laura Palmer. Laura often behaves like a man: she frequently betrays her boyfriend Bobby Briggs (Dana Ashbrook), leads a very promiscuous sexual life and prostitutes herself as well as she often buys drugs and additively consumes them. All of these transgressions from the behaviour expected from a seventeen-year-old girl 
belonging to a respectable middle-class family have been recognized as the only way for her to evade and cope with the cruel reality of family abuse (Plummer 309; Alexander 140).

As many critics have noted, this is the case of Leland as well. As Laura's father confesses during the final moments of his life in "Episode 16" (directed by Tim Hunter), he is a victim of the spirit BOB (Deutsch 148-49). ${ }^{(2)}$ In particular, he is a sexual victim. In fact, Leland states: "I invited him [BOB], and he came inside me". This sentence has clear sexual implications. Leland has probably been sexually harassed and has been forced to assume a woman's passive sexual role. This is the first time he confesses such a terrible truth, just a few moments before dying, but only after BOB has definitely abandoned him. ${ }^{(3)}$ The viewer is allowed to think that nobody intervened when he was abused by BOB, that every citizen of Twin Peaks preferred to ignore such an issue and respect the cover of public bourgeois life, precisely as it occurs in the case of Laura. ${ }^{(4)}$

The narratives of Laura and Leland are therefore based on the secret side of the bourgeois family home. It is the story of two persons who have been violated in their youths. We can then agree with Helen Deutsch when affirming that the rape story constitutes "a plot about seeing and knowing, or, [ . . .] of failing to see or to know" (139-40). In the case of Twin Peaks, the truth to be seen and known is that of the violence present in the white, middle-class home, the violence perpetuated by the patriarchal order over women, children and adolescents. Such a truth needs to be kept secret, private and confined within the domestic walls: unveiling the evils of the patriarchal system cannot be tolerated by its representatives.

Many critics have therefore maintained that BOB is a representation of "the dominance of phallic power" (Nochimson The Passion 88) in patriarchal society, of the bourgeois order which forces people to lead a double life characterised by an appearance of benevolence and kind behaviour in public on the one hand, and a secret, hidden existence devoted to what society would condemn on the other hand (O'Connor 318). BOB silences all the persons who could expose the truth of patriarchy, as in the specific cases of Leland's wife Sarah (Grace Zabriskie) and Laura's friend Ronette Pulaski (Phoebe Augustine). Indeed, Leland secretly puts drugs in his wife's glass of milk every time he wants to enter his daughter's room to rape her. He gives Sarah the drugs also before killing his nephew Maddy Ferguson, thus making a drug addict of his wife and preventing her from knowing the truth of domestic violence. Similarly, Ronette - the only female character who survives the encounter with the evil spirit - is severely beaten by Leland and suffers a great trauma. She subsequently falls into a coma and becomes almost mute. In this way, she is prevented from unmasking bourgeois' corrupt side.

Leland himself is murdered for the same reason. For all of his life he has not revealed the wicked acts of patriarchy. Once he has been arrested by Cooper, he confesses the murders of Teresa, Laura and Maddy and explicitly states: "They made me kill that girl, Teresa. [. . .] They made me kill [Laura]". We could think that the term "they" refers to the representatives of the patriarchal order. In his last confession, Leland thus unveils their evils: he unmasks the sexist actions of the bourgeois order, revealing what actually happens inside the walls of middle-class homes. He is therefore punished by being killed for allowing the truth to be explicitly stated. Similarly, Laura is silenced by being murdered. As viewers are shown in the prequel film Fire Walk with $M e$, after five years of abuse, she stops splitting her abuser into a distinct personality (Stevenson 76) - a typical defensive mechanism of rape victims - and stops "creat[ing] a bestial face for her nocturnal intruder" (Alexander 140).

She recognizes her father as the man who enters her room through the window during the night. This happens exactly the night before being killed. She finally realizes the truth about BOB, that is, the truth about patriarchy, and is killed in order for patriarchy to survive through the bourgeois double way of life. Her scream of denunciation does not reach out the bourgeois home and she is not able to reveal the truth of domestic violence. This is epitomized by the passages of the film which depict her last day, when she silently cries in the classroom (Angelo Badalamenti's soundtrack completely covers her words and sobs in this specific scene) as well as when she decides not to tell her lover James Hurley (James Marshall) the truth about BOB.

We should also consider that, in "Episode 10" (directed by Lesli Linka Glatter), Leland affirms that he has encountered BOB when he was a boy and has therefore been possessed by the evil spirit throughout his whole life. He then married his wife Sarah and impregnated her with Laura. In this way, we could legitimately 
argue that Laura is also BOB's daughter. Could we not affirm, then, that her "maleness", her masculinity is inherited from BOB himself? She could therefore be seen as a daughter of patriarchy, herself enacting a masculine behaviour by means of a promiscuous sexual life and the use of drugs. BOB thus kills the "phallic" woman he himself gave life to because she refuses to submit to the rules of bourgeois society and to respect conventional gender positions. Indeed, as Leland specifies before dying in "Episode 16", Laura "was strong, she fought him, she wouldn't let him in". The young girl does not want to be possessed by BOB, but chooses to die instead. She refuses to impersonate, to be a vehicle for or, in Leland's words, "to be used" by patriarchy and to enact a properly feminine conduct.

A comparison could be made between Leland Palmer and all of his victims. In Fire Walk with Me, for example, the viewer discovers that Laura's father and Teresa Banks are lovers. Leland, although married, frequently visits the young girl and pays money for their sexual encounters. Teresa is an independent woman, who lives on her own, but is also a prostitute who organizes and participates in orgies. Both Leland and Teresa behave in a very masculine way and have a promiscuous sexual life.

After discovering that Leland is probably the father of her friend and sexual partner in prostitution Laura, Teresa tries to blackmail him by threatening to reveal their illicit relationship. She is then "silenced" by BOB in order not to have patriarchy's secret actions publicly unmasked. BOB kills Teresa because he must safeguard the illusions and pretensions of the bourgeois perfect home and family life. As I have demonstrated earlier, this is also the case of Leland's death. Leland is forced by BOB to commit suicide because he does not agree with the representatives of patriarchy who want to protect bourgeois double life. Nochimson points out that Teresa Banks's scream "No" at the beginning of Lynch's film, when imploring for her own life, is very similar to Leland's scream at the end of the film, when killing Laura (The Passion 192). In this occasion, Leland cries: "No. [. . . ] Don't make me do this". He seems to be appealing to BOB in order to be spared the anguish and regrets committing the murder of his own daughter. The identification of these characters with one another thus occurs through the very words they both say, through their plea to the patriarchal order whose rules they have not respected or followed. Both Leland and Teresa are victims of male power and abuse.

Such a parallel could also be established in regard to all of BOB's victims. Firstly, Laura and her cousin Maddy are represented as physically similar because the two characters are played by the same actress. Secondly, Laura's and Maddy's personal behaviours are presented as very similar. Maddy arrives at Twin Peaks for her cousin's funeral and decides to live in the Palmers' house and be close to her relatives in the moment of grief ("Episode 3").

In "Episode 14", she decides to go back to Missoula, where, in her own words, "I got my job, my apartment and I just miss having a life of my own". After Leland listens to this, he is forced by BOB to kill her by smashing her face against a drawing of Missoula on the wall. Maddy is murdered because she wants to behave like a man by being independent in her life and choices. With Maddy's death, patriarchy is protected and men's subjection of and control over women as well as women's confinement to the house and to the rules of the father are ensured. ${ }^{(5)}$ All of the women killed by BOB refuse to be confined to the domestic space of the bourgeois home and do not want to be ruled by the father. They do this by behaving themselves as men and, therefore, by imitating the behaviour of BOB himself. This is all the more true if we consider that the letters BOB leaves under the nails of his female victims immediately after murdering them would form the word "Robertson", son of Robert. In this way, the women killed by BOB are named as if they were his sons: they are explicitly defined as masculine.

Another identification could be made between Laura and agent Cooper. Firstly, both Laura and Cooper experience BOB's possession and are pictured in front of a mirror in which BOB is reflected. This occurs in both cases a few moments before they die because of the evil spirit. Indeed, near the end of Fire Walk with $M e$, Laura is brought by Leland to an abandoned railway carriage and tightly bound with ropes. Leland then places a mirror in front of her face in which she sees BOB's reflection before being brutally murdered. Similarly, in "Episode 29", after escaping from the Black Lodge where BOB resides, Cooper enters the bathroom of his hotel room and, in a repetition of Leland's and Maddy's deaths, violently strikes his forehead against the mirror, in which the viewer is immediately shown BOB's reflection. Secondly, Cooper himself enacts an inversion of gender roles. In the course of the story, in fact, the FBI agent, contrary to the typical 
masculine methods of detective-investigation (such as scientific examination and rational explanation of the evidence), mainly recurs to feminine techniques of detection (such as dreams, intuitions and subconscious information) as the fittest to enlighten him on the murder case (Deutsch, 142 Stewart 39). He also refuses any sexual contact with women, though he has been offered it on several occasions by the beautiful and young Audrey Horne (Sherilyn Fenn), to whom he explicitly admits to be attracted. Cooper thus assumes a woman's position by choosing to be courted instead of courting a woman himself. He seems to avoid active sexuality and the role of a patriarchal man.

However, it is symptomatic that, once Cooper has a physical relationship with his girlfriend Annie Blackburn (Heather Graham) - and is therefore able to behave like a proper white and middle-class male - he becomes a prey to BOB. In the series finale, we could argue, he takes the role of a proper patriarchal white male only when possessed by the malevolent spirit. The very fact that, when reflecting the image of BOB in the mirror, Cooper repeatedly asks the question "How is Annie?" while laughing and parodying his own interest in the fate of his girlfriend, could hint at the fact that he actually does not care about her. According to this view, he would be interested only in possessing a woman and controlling her. This could be evidenced by the fact that, in this scene, Cooper empties the toothpaste-tube in the basin. This action could be read as a sexual allusion to a male orgasm. In this moment, Cooper has terminated his role during the sexual act. Actually, this is not the representation of a sexual act, but of an act of masturbation aimed at no procreation, an act in which a woman is not necessary to reach pleasure. Cooper then dies before fully actuating the rules of patriarchy over Annie. We could also say that he is killed because of the reversal of gender role he has enacted throughout the series when implicitly refusing to assume a patriarchal and properly masculine behaviour.

On the other hand, according to the interpretation of the series' final episode given by Marc Dolan (43) and Mark Allyn Stewart (48), Cooper confronts and then struggles against his evil double, his shadow soul and it is the latter who escapes from the Black Lodge and subsequently commits suicide in the hotel's bathroom. The real, good Cooper is imprisoned in the Black Lodge with Laura, as it is shown also in the ending of Fire Walk with Me. Laura and Cooper could then be said to share eternity. Laura could even be identified with Cooper's object of desire. Throughout the series, in fact, the FBI agent searches for the truth on the young girl, analysing her body as well as reconstructing her story. The narrative of Twin Peaks is largely based on the reconstruction of the identity of Laura's killer as much as of the girl's past and death. As Laura Plummer argues, the story "works to discover Laura Palmer [. . .] [who] must be 'detected' in the same manner [as the killer]" (308).

Laura and BOB are the objects of Cooper's investigation: the FBI agent searches for the truth behind both of them. In a certain way, we could then argue that Cooper finds the object of his desire when he is finally joined with Laura in the Black Lodge. This could be confirmed also by the fact that, as Paul A. Woods has noted, the credits of the second series' final episode play out over Laura Palmer's reflection in a coffee cup (146). Laura and Cooper are identified by the union of her image with the coffee the FBI agent repeatedly asks for and consumes in each episode of the series. In the Black Lodge, Cooper enjoys both Laura's presence and the coffee for eternity. The realization of the desires and motives which founded his actions throughout the narrative is finally achieved by him in this representation of the afterlife.

Reversal of gender roles is therefore evident in Twin Peaks and Fire Walk with Me. In these works, all of the women killed by BOB exhibit patriarchal attitudes, want to be independent or engage in masculine activities such as drug addiction and traffic or sexual promiscuity. All of BOB's victims and possessions can be compared to each other through a reading explaining their behaviours as contrary to the gender codes prescribed by patriarchal, white and middle-class males. The characters who refuse to publicly behave according to the rules of patriarchy (which strictly establish and enforce the codes specific to each sex) are punished by being silenced. Bourgeois values cannot be reversed, even though a positive message seems to be finally offered by Lynch in the prequel film. If we agree with Angela Hague (140) when stating that the Black Lodge and the White Lodge are represented exactly as the same place and that, therefore, hell and heaven coincide in the vision of Lynch, we could affirm that Cooper and Laura are united in a happy afterlife where angels and joy reign. Indeed, in the final scene of Fire Walk With Me (which was anticipated by Cooper's dream sequence in "Episode 2"), the FBI agent and Laura are pictured together in this sort of afterlife. Cooper smiles at Laura, who is shown as deeply sad until an angel appears in front of them and 
she begins crying tears of joy.

This is the very last image of the two protagonists given by Lynch, with which the narrative of the film (and the series) definitely concludes. The very presence of an angel could testify to Laura's and Cooper's liberation from the patriarchal order that caused their deaths. This would be confirmed by the fact that the angel depicted in this scene as much as the angel appearing before Laura's death are pictured as feminine creatures. These are "female angels", as silent as Laura, Maddy, Ronette and Teresa have all been silenced. No voice or sound, in fact, can be heard during their apparitions.

They can be seen as representing the lack of power on women's part to expose the evils of patriarchy. The White Lodge being the locus where spiritual perfection is achieved (Hague 140), it therefore also represents a liberating eternity where patriarchal rules and codes of behaviour are not applied, where each individual can freely act without gender identification. Laura and Cooper, the two protagonists of Twin Peaks and Fire Walk with $M e$, are respectively shown as crying tears of joy and comfortably smiling: they finally experience freedom and a joyful liberation from patriarchy. The central dynamic of the extended narrative of the TV series and the film could therefore be thought of as an escape from patriarchy.

\section{Notes}

1. As Lynch admitted: "They forced us to [. . . ] get to Laura's killer. It wasn't really all their fault [. .

.] The pressure was just so great that the murder mystery couldn't be just a background thing any more" (Lynch 177).

2. This has been clearly stated by David Lynch as well (180).

3. Leland's final confession is uttered in a scene which is filled with references to the inversion of gender roles. Indeed, during the final moments of Leland's life, agent Cooper is shown as lingering over the man's body. As Martha P. Nochimson has suggested, this image is a clear reminder of Michelangelo's statue Pietà ("Desire" 31). Cooper assumes a female role by representing the Holy Mary crying over the body of Christ, an innocent violated by a society that would not believe in his words.

4. This is rendered explicit during the girl's funeral in "Episode 3" (directed by Tina Rathborne), when Bobby affirms: "Everybody knew she was in trouble, but we didn't do anything, all you good people".

5. As Deutsch has pointed out (145), Maddy's death, her being silenced by patriarchy, is reproduced and repeated with Leland's suicide in "Episode 16". Identity is established between Leland and Maddy (as much as between Leland and Cooper) through their deaths. Indeed, after being incarcerated by the FBI agent and after confessing the murders he has committed, Leland is forced by BOB to repeatedly strikes his forehead against the cell's window until he suffers a fatal wound.

\section{References}

Alexander, John. The Films of David Lynch. London: Charles Letts, 1993.

Desmet, Christy. "The Canonization of Laura Palmer." Full of Secrets: Critical Approaches to Twin Peaks. Ed. David Lavery. Detroit, MI: Wayne State UP, 1995. 93-108.

Deutsch, Helen. "'Is It Easier to Believe?' Narrative Innocence from Clarissa to Twin Peaks." Arizona Quarterly 49:2 (Summer 1993): 137-58.

Dolan, Marc. "The Peaks and Valleys of Serial Creativity: What Happened to/on Twin Peaks." Full of Secrets: Critical Approaches to Twin Peaks. Ed. David Lavery. Detroit, MI: Wayne State UP, 1995. 30-50.

Hague, Angela. "Infinite Games: The Derationalization of Detection in Twin Peaks". Full of Secrets: Critical Approaches to Twin Peaks. Ed. David Lavery. Detroit, MI: Wayne State UP, 1995. 130-43.

Hume George, Diana. "Lynching Women: A Feminist Reading of Twin Peaks." Full of Secrets: Critical Approaches to Twin Peaks. Ed. David Lavery. Detroit, MI: Wayne State UP, 1995. 109-19. 
Jenkins, Henry. "'Do You Enjoy Making the Rest of Us Feel Stupid?': alt.tv.twinpeaks, the Trickster Author, and Viewer Mastery." Full of Secrets: Critical Approaches to Twin Peaks. Ed. David Lavery. Detroit, MI: Wayne State UP, 1995. 51-69.

Lynch, David. Lynch on Lynch. Revised Edition. Ed. Chris Rodley. London: Faber and Faber, 2005.

Nochimson, Martha P. "Desire Under the Douglas Firs: Entering the Body of Reality in Twin Peaks." Film Quarterly 46:2 (Winter 1992-93): 22-34. . Passion of David Lynch: Wild at Heart in Hollywood. Austin, TX: U of Texas P, 1997.

O'Connor, Tom. "Bourgeois Myth versus Media Poetry in Prime-Time: Re-visiting Mark Frost and David Lynch's Twin Peaks." Social Semiotics 14:3 (Dec. 2004): 309-33.

Phelps, Lori. "The Resurrection of Nature in Twin Peaks." The Image of Nature in Literature, the Media, and Society. Ed. Will Wright and Steve Kaplan. Pueblo, CO: The Society for the Interdisciplinary Study of Social Imagery, 1993. 2-5.

Plummer, Laura. "'I'm not Laura Palmer': David Lynch's Fractured Fairy Tale." Literature/Film Quarterly 25:4 (1997): 307-11.

Richardson, John. "Laura and Twin Peaks: Postmodern Parody and the Musical Reconstruction of the Absent Femme Fatale." The Cinema of David Lynch: American Dreams, Nightmare Visions. Ed. Erica Sheen and Annette Davison. London: Wallflower Press, 2004. 77-92.

Stevenson, Diane. "Family Romance, Family Violence, and the Fantastic in Twin Peaks." Full of Secrets: Critical Approaches to Twin Peaks. Ed. David Lavery. Detroit, MI: Wayne State UP, 1995. 70-81.

Stewart, Mark Allyn. David Lynch Decoded. Bloomington, IN: Author House, 2007.

Woods, Paul A. Weirdsville USA: The Obsessive Universe of David Lynch. London: Plexus, 2000.

\section{Film and Television}

Fire Walk with Me. Dir. David Lynch. New Line Cinema, 1992.

"Episode 2." Twin Peaks. Dir. David Lynch. Lynch/Frost Productions, 1990.

"Episode 3." Twin Peaks. Dir. Tina Rathborne. Lynch/Frost Productions, 1990.

"Episode 7." Twin Peaks. Dir. Mark Frost. Lynch/Frost Productions, 1990.

"Episode 10." Twin Peaks. Dir. Lesli Linka Glatter. Lynch/Frost Productions, 1990.

"Episode 14." Twin Peaks. Dir. David Lynch. Lynch/Frost Productions, 1990.

"Episode 16." Twin Peaks. Dir. Tim Hunter. Lynch/Frost Productions, 1990.

"Episode 24." Twin Peaks. Dir. James Foley. Lynch/Frost Productions, 1991.

"Episode 29." Twin Peaks. Dir. David Lynch. Lynch/Frost Productions, 1991.

\section{Author Information}

Antonio SANNA received his $\mathrm{PhD}$ at the University of Westminster in London. His publications include articles on James's "The Turn of the Screw", Stoker's Dracula, H. G. Wells's The Island of Dr. Moreau, Victorian ghost stories and Beowulf; the Alien quadrilogy, Ridley Scott's Hannibal and the Harry Potter films. He has contributed to The Dictionary of Literary Characters. 